\title{
Ministernotomy approach for modified Blalock-Taussig shunts in neonates: a feasibility study
}

\author{
Ashraf A. H. El Midany ${ }^{*}$ (D) and Ayman A. Doghish
}

\begin{abstract}
Background: The original approach to performing a modified Blalock-Taussig (MBT) shunt is via a left thoracotomy. However, the median sternotomy has become the preferred approach of many surgeons. We think that the upper ministernotomy approach provides several advantages and avoids the disadvantages of both the sternotomy and thoracotomy approaches. Here, we describe our experience in constructing neonatal MBT shunts via upper ministernotomy.

Methods: A prospective study was conducted on 50 neonates who underwent modified Blalock-Taussig shunt performed through upper ministernotomy between March 2011 and December 2016. Preoperative characteristics, mortality, and morbidity were recorded.

Results: Mean age was $16.9 \pm 10.4$ days, and weight was $3.5 \pm 0.5 \mathrm{~kg}$. All patients received grafts of size $3.5 \mathrm{~mm}$. The mean oxygen saturation increased from $59.5 \pm 7.3 \%$ preoperatively to $84.8 \pm 4.2 \%$ postoperatively. There were three cases of mortality (6\%). One patient suffered from an unstable sternum (2\%). No patients required conversion to full sternotomy. Superficial wound infection occurred in three cases (6\%), and there were no cases of mediastinitis. Mean duration of ventilation was $55.64 \pm 37.5 \mathrm{~h}$, mean ICU stay was $5.44 \pm 3.9$ days, and mean hospital stay was $14.7 \pm 7.2$ days.

Conclusion: Upper ministernotomy is a safe approach with good early results. It provides adequate exposure with limited surgical trauma. Emergency conversion to full sternotomy and initiation of cardiopulmonary bypass can be achieved easily. It avoids lung compression and respiratory compromise. Additional costs for specific instruments are not necessary.
\end{abstract}

Keywords: Modified Blalock-Taussig shunt, Neonatal Blalock shunt, Surgical approach, Ministernotomy, Congenital cyanotic heart disease

\section{Background}

In the current era, biventricular corrective surgery is the preferred approach for neonates or young infants, whenever possible. However, palliative systemic-pulmonary arterial shunt is still needed in cases of single ventricle physiology, reduced pulmonary blood flow with vital instability, and in resource-limited regions where funding for open heart procedures, especially in such high-risk patient groups, is not available.

\footnotetext{
* Correspondence: ashelmidany@gmail.com

Department of Cardiovascular \& Thoracic Surgery, Faculty of Medicine, Ain Shams University Hospital, Cairo 11588, Egypt
}

The modified Blalock-Taussig (MBT) shunt was introduced as one of many options for connecting the systemic and pulmonary circulations and involves a polytetrafluorethylene (PTFE) tube graft being inserted between the subclavian and pulmonary arteries. It has become a widely accepted palliative procedure due to the low morbidity and mortality rates associated with the procedure [1-3].

The original approach for the MBT shunt, as described by de Leval and co-workers, was via a left thoracotomy [4]. However, in recent times, the median sternotomy has evolved to become the preferred approach of many surgeons. Some of the reasons for this include the following: 
it is a less demanding operation, it provides greater control of the blood vessels without the risk of respiratory compromise due to lung compression, and it enables construction of the anastomosis at the side of the superior vena cava for possible correction of pulmonary artery distortion during later conversion to the bidirectional Glenn [5]. However, subsequent procedures require repeat sternotomy, which is more time consuming and carries greater risk due to sternal adhesions.

The upper ministernotomy approach to MBT shunt construction has not been described in the literature. We believe that it can provide adequate exposure and easy construction of an anastomosis and carries less risk for subsequent sternal re-entry. In this report, we study the feasibility of MBT shunt construction in neonates via upper ministernotomy. Our endpoints include mortality and morbidity in terms of sternal stability, pulmonary mechanics reflected by the presence of lung collapse and duration of mechanical ventilation, and superficial and deep wound infections.

\section{Methods}

\section{Preoperative characteristics}

After receiving approval from the local ethics committee in Faculty of Medicine at Ain Shams University, a prospective study was conducted on 50 successive neonate patients between March 2011 and December 2016. All neonates who presented with desaturation due to decreased pulmonary blood flow and scheduled for an MBT shunt were included in the study. Patients who required cardiopulmonary bypass for other concomitant procedures, such as pulmonary artery reconstruction, unifocalisation of collaterals, and Norwood, were excluded from the study. However, off-pump pulmonary artery reconstruction was not an exclusion criterion.

Preoperative diagnoses are summarised in Table 1.

Table 1 Preoperative patient characteristics

\begin{tabular}{ll}
\hline Variable & $\begin{array}{l}\text { Number (percentage) } \\
\text { (Total number = 50) }\end{array}$ \\
\hline Demographics & $21(42 \%)$ \\
Male & $29(58 \%)$ \\
Female & \\
Preoperative diagnosis & $18(36 \%)$ \\
PA-IVS & $15(30 \%)$ \\
PA-VSD & $5(10 \%)$ \\
TGA, VSD, PS & $9(18 \%)$ \\
Tricuspid atresia & $3(6 \%)$ \\
TOF/DORV & \\
\hline
\end{tabular}

PA pulmonary atresia, IVS intact interventricular septum, VSD ventricular septal defect, TGA transposition of great arteries, PS pulmonary stenosis, TOF tetralogy of Fallot, DORV double outlet right ventricle
All patients underwent regular preoperative medical examination and laboratory investigations. Informed written consent was obtained from each patient's guardian(s).

Diagnosis was achieved via echocardiographic and multislice computed tomography (MSCT) examinations to establish the intracardiac anatomy, the systemic and pulmonary vessel distribution and dimensions, and the presence, site, and size of patent-ductus arteriosus (PDA).

\section{Operative procedure}

All patients received intramuscular ketamine $(3 \mathrm{mg} / \mathrm{kg})$ for sedation and stress-free separation from their parents. In the operating room, patients were monitored using five-lead ECG, pulse oximetry $\left(\mathrm{SpO}_{2}\right)$, capnography for end-tidal carbon dioxide (Drager PM 8040CATO, lübeck, Germany), planter surface temperature, and invasive blood pressure. Central venous catheters and arterial catheters were inserted after induction of general anaesthesia. Mechanical ventilation was provided by a Narkomed anaesthesia machine (North American Drager, Telford, PA) with fractional inspiratory oxygen concentration $\left(\mathrm{fiO}_{2}\right)$ maintained 0.9 and 1.0. The endtidal carbon dioxide $\left(\mathrm{CO}_{2}\right)$ was maintained between 35 and $40 \mathrm{mmHg}$, using a tidal volume of $10 \mathrm{~mL} / \mathrm{kg}$ and respiratory rate adjusted according to age. Positive endexpiratory pressure of $2-5 \mathrm{cmH}_{2} \mathrm{O}$ and inspiratory to expiratory ratio (I:E ratio) of 1:1.5-1:2 were used.

All MBT shunt procedures were performed via upper ministernotomy. A small skin incision was made from 0.5 $\mathrm{cm}$ below the suprasternal notch to $1 \mathrm{~cm}$ below the sternal angle. Then, the manubrium and the sternum were divided longitudinally in a J-shaped manner, using Mayo scissors up to the level of the third right intercostal space. After opening the sternum, the right lobe of the thymus was excised; the innominate artery was dissected up to its branches, with dissection of the right subclavian artery. The pericardium was opened above the aorta and stay sutures were inserted. The right pulmonary artery, between the ascending aorta and the superior vena cava up to the upper lobar branch, was dissected.

The systemic site of the shunt insertion was either the innominate or right subclavian artery, and the site of the distal anastomosis was the right pulmonary artery as close to the middle line as possible.

The systemic artery was partially clamped with a Cooley clamp, and a longitudinal arteriotomy was performed at the undersurface of the artery. A transversely cut polytetrafluoroethylene (Gore-Tex) tube graft (W. L. Gore \& Associates, Inc., USA) was sutured end-to-side to the arteriotomy. The clamp was then released in situ to ensure good shunt flow and a competent anastomosis. The systemic artery was clamped again, and the shunt was flushed by heparinised saline to flush any thrombi, then the shunt was trimmed to the appropriate length. 
The right pulmonary artery was partially clamped with a Cooley clamp, and an end-to-side distal anastomosis was performed in the same way (Figs. 1, 2, and 3).

All neonates in this series received $3.5-\mathrm{mm}$ grafts, and the ductus was not ligated.

Before closure, haemostasis was secured, and a retrosternal drain was inserted

\section{Postoperative events}

Postoperatively, all neonates were ventilated. After haemostasis was ascertained, heparin was administered as a continuous infusion at $10-20 \mathrm{units} / \mathrm{kg} / \mathrm{h}$ and was later changed to an oral low dose of aspirin $(5 \mathrm{mg} / \mathrm{kg} /$ day). All patients received a postoperative echocardiographic examination to check the patency of the shunt

\section{Study endpoints}

Study endpoints were in-hospital mortality, reoperation for immediate shunt-related complications (thrombosis or anastomotic stenosis), conversion to full sternotomy, duration of ventilation, intensive care unit (ICU) stay, hospital stay, postoperative peripheral oxygen saturation $\left(\mathrm{SaO}_{2}\right)$ at discharge, and postoperative complications in terms of respiratory failure, re-exploration for bleeding, unstable sternum, superficial wound infections, and mediastinitis.

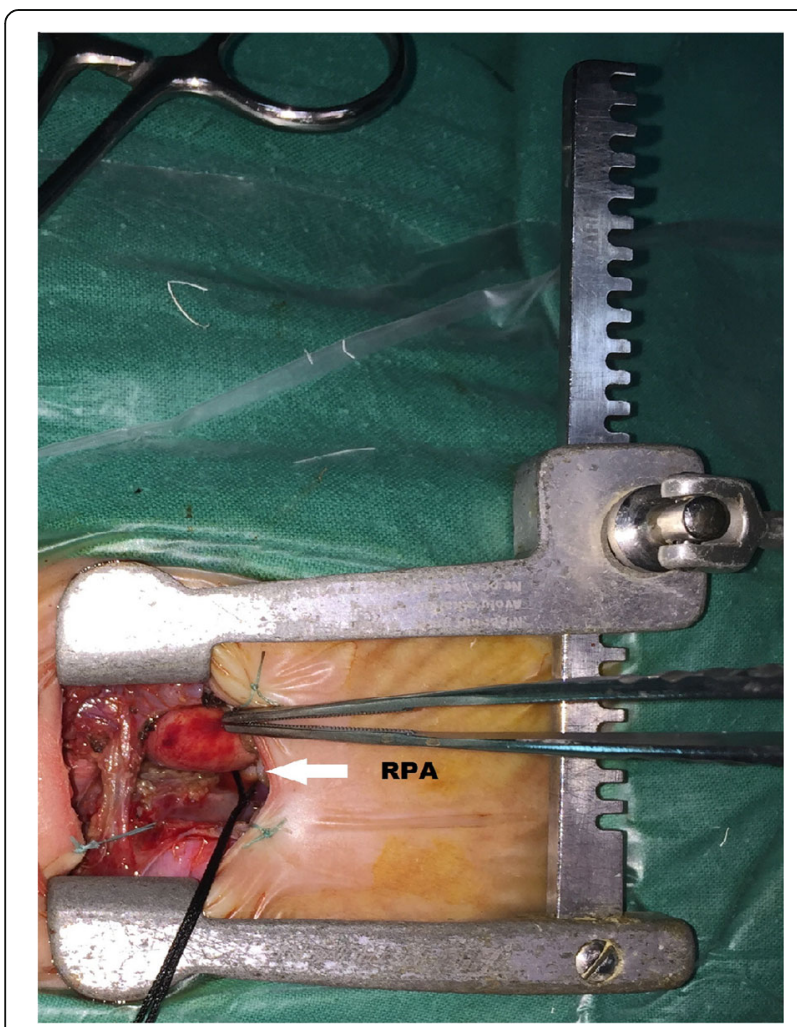

Fig. 1 Operative view showing the right pulmonary artery via the ministernotomy approach. RPA right pulmonary artery

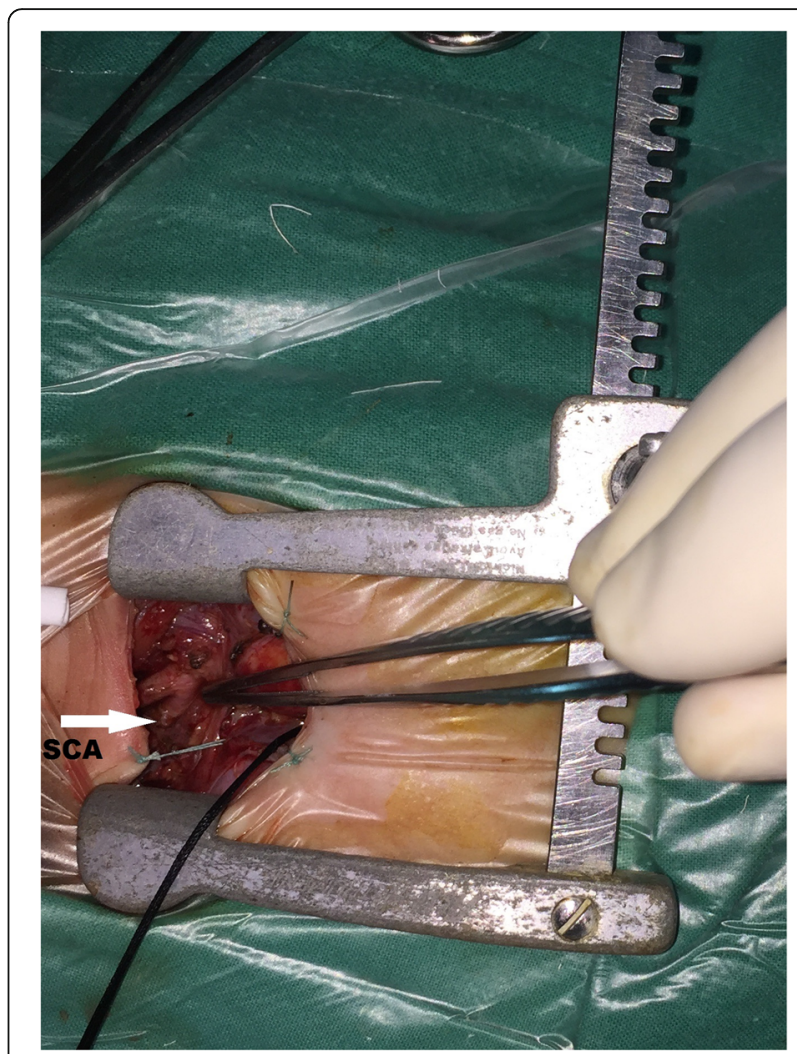

Fig. 2 Operative view showing the right subclavian artery via the ministernotomy approach. SCA subclavian artery

\section{Statistical analysis}

The collected data were revised, tabulated, and analysed using Statistical package for Social Science (SPSS) version 25 (SPSS, Inc., Chicago, IL, USA). Statistical data were expressed as mean \pm standard deviation (SD) for continuous variable or as value and percentage for categorical data.

\section{Results}

All 50 patients were enrolled in the study. No patient required conversion to full sternotomy or emergency cardiopulmonary bypass. The mean age of the patients was $16.9 \pm 10.4$ days, and the mean weight was $3.5 \pm 0.5 \mathrm{~kg}$.

\section{Mortality}

There were three in-hospital deaths (6\%). The causes of death were low cardiac output, sepsis, and acute respiratory distress syndrome (ARDS).

\section{Outcomes}

The mean preoperative $\mathrm{SaO}_{2}$ was $59.5 \pm 7.3 \%$, and the postoperative saturation was $84.8 \pm 4.2 \%$. The mean duration of ventilation was $55.64 \pm 37.5 \mathrm{~h}$, mean ICU stay was $5.44 \pm 3.9$ days, and the mean hospital stay was $14.7 \pm 7.2$ days. 


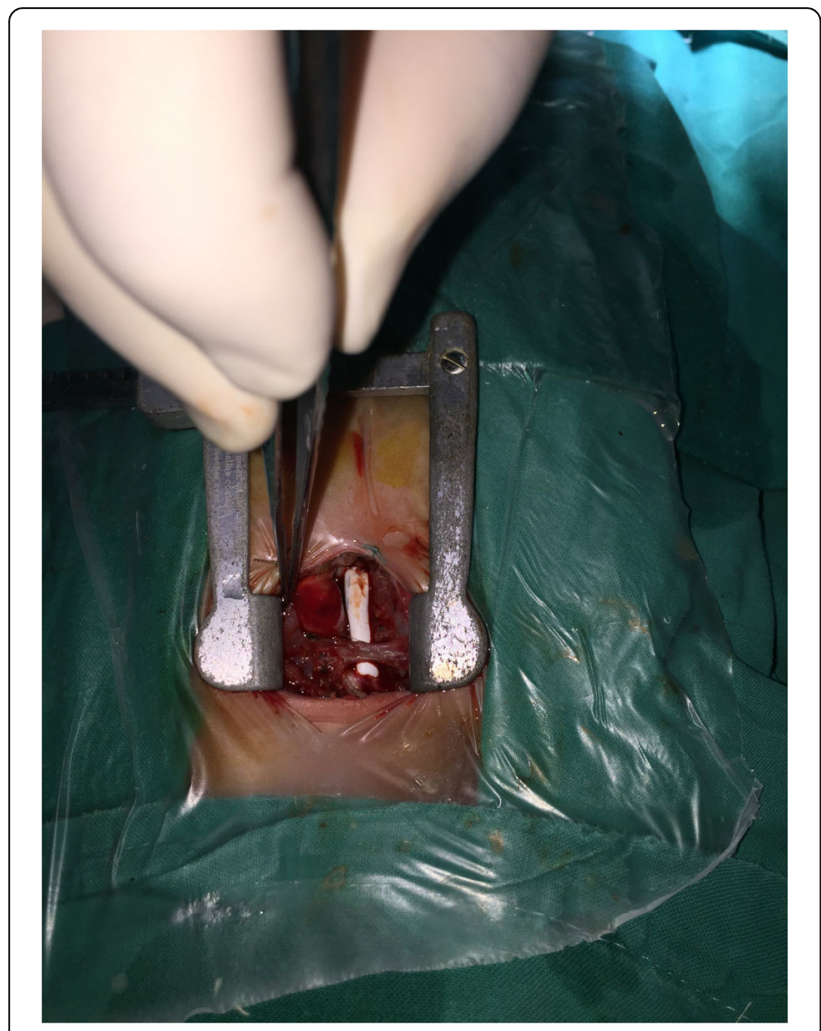

Fig. 3 Operative view of the MBT shunt constructed via upper ministernotomy in a neonate patient

\section{Morbidity}

Shunt thrombosis occurred in two (4\%) patients who needed shunt revision and the graft was replaced with one of the same size. Shunt overflow was reported in five cases $(10 \%)$, and there were no cases of shunt failure due to small shunt size. One case had an unstable sternum after re-exploration for shunt revision. The stainless wires were broken, and re-exploration was required for sternal fixation. No cases required re-exploration for bleeding. Superficial wound infection occurred in three patients $(6 \%)$, which were all treated properly by repeated dressing changes and antibiotics. There were no cases of mediastinitis (Table 2).

\section{Discussion}

Minimal-access approaches have become more popular and widely used in paediatric cardiac surgery in recent times. They reduce surgical trauma, morbidity, and length of hospital stay. They have been reported to be associated with less blood transfusion and less postoperative pain [6-8]. There are several incision options for different minimally invasive approaches, based on the operation needed, including the parasternal incision, lateral thoracotomy, and upper or lower partial ministernotomy. The main concepts for all approaches are to provide adequate surgical exposure and the certain
Table 2 Mortality and morbidity

\begin{tabular}{ll}
\hline Outcome & $\begin{array}{l}\text { Number (percentage \%) } \\
\text { (Total number =50) }\end{array}$ \\
\hline Mortality & $3(6 \%)$ \\
Morbidity & \\
Shunt overflow & $5(10 \%)$ \\
In-hospital shunt thrombosis & $2(4 \%)$ \\
Unstable sternum & $1(2 \%)$ \\
Superficial wound infection & $3(6 \%)$ \\
\hline
\end{tabular}

safety of the procedure [9]. MBT shunt was classically performed via the thoracotomy approach. Although it is a minimal access incision that gives good surgical exposure and adhesion-free mediastinum on subsequent sternotomy, it does not provide complete safety of the procedure in terms of overlooking some cardiac anomalies that may be missed in the preoperative diagnosis. In addition, it lacks the cosmetic advantage by making a second scar on the chest. It also has potential disadvantages, such as chylothorax, pulmonary artery distortion, and preferential pulmonary blood flow [1]. Many authors have reported the advantages of the sternotomy approach for MBT shunt; it provides good exposure of the vessels, easy control of patent ductus arteriosus, initiation of cardiopulmonary bypass if necessary, and easy takedown of the shunt and reconstruction of the pulmonary artery during later procedures. Moreover, it avoids lung compression, respiratory compromise, late scoliosis, and a second chest scar $[1,3,10,11]$.

We aimed to provide the advantages but avoid the disadvantages of both sternotomy and thoracotomy approaches, via a minimal access upper ministernotomy approach. We found adequate exposure for construction of the MBT shunt, and we did not need any special instruments or devices. Thorough exploration of other cardiac defects, pulmonary artery branch size and distribution, and patent ductus arteriosus was easily carried out. Conversion to full sternotomy and initiation of cardiopulmonary bypass is also possible; however, it was not needed in our study.

Many authors have reported advantages of ministernotomy compared to median sternotomy, including less surgical trauma, less blood transfusion, less postoperative pain, better recovery, and shorter hospital stay $[6,7$, $9,12]$. Nevertheless, others disagree and have reported contrary results, for example, Aris et al. [13] reported that ministernotomy did not reduce the length of hospital stay, postoperative pain, or bleeding, and Laussen and colleagues [14] failed to demonstrate better patient recovery in minimally invasive incisions.

We did not objectively assess postoperative pain or pulmonary function because they are difficult to measure in this age group. However, diminished surgical 
trauma and nearly intact chest cage resulted in good patient recovery and respiratory mechanics. This can be noticed in the average results for mechanical ventilation, ICU stay, and length of hospital stay.

All MBT shunt patients will require a second procedure for biventricular repair or Fontan operation. Therefore, the ministernotomy approach in such patients has a peculiar advantage as it exposes only a limited portion of the great vessels, thereby saving the cardiac chambers, especially the right ventricle. Therefore, it results in fewer sternal adhesions, minimising the risks of cardiac injury and blood loss on sternal re-entry. Moreover, subsequent operation(s) with a single scar on the chest provide a cosmetic advantage. The smaller surgical incision results in limited soft tissue dissection with reduced risk of postoperative soft tissue infections and mediastinitis [15], and this explains our results that show a low incidence of superficial soft tissue infection and no cases of mediastinitis.

\section{Study limitations and future prospective}

This was a prospective feasibility study to show that the procedure is possible with no major complications. The number of patients in the study was limited, and the study focused on only the short-term outcomes. Further studies are needed to compare this approach with others and to report the long-term follow-up and the potential advantages of the ministernotomy approach in the second stage operations.

\section{Conclusion}

Upper ministernotomy is a safe alternative approach for MBT shunt in neonates. It provides the advantages of adequate exposure with less surgical trauma. It avoids lung compression and respiratory compromise, and there is no technical compromise in the construction of the anastomosis. In addition, extra costs for specific instruments are not necessary. Further comparative studies with long-term follow-ups are essential.

\section{Acknowledgements}

Not applicable

\section{Authors' contributions}

AAH created the idea of the operations and performed most of them, collected the data, participated in the design of the study, and drafted the manuscript. AD performed some of the operations, participated in the collection of data, participated in the sequence alignment, performed the statistical analysis, and helped to draft the manuscript. Both authors read and approved the final manuscript.

\section{Funding}

Self-funded

\section{Availability of data and materials}

The datasets used and/or analysed during the current study are available from the corresponding author on reasonable request
Ethics approval and consent to participate

The study has been approved by Local Ethics Committee in the Faculty of Medicine at Ain Shams University, and informed written consent was obtained from each patient's parents as a routine preoperative step.

\section{Consent for publication}

A written consent for participation in medical research has been obtained from each patient's parents as a routine institutional step on admission of the patient.

\section{Competing interests}

The authors declare that they have no competing interests.

Received: 29 May 2019 Accepted: 5 June 2019

Published online: 15 July 2019

\section{References}

1. Shauq A, Agarwal V, Karunaratne A, Gladman G, Pozzi M, Kaarne M et al (2010) Surgical approaches to the Blalock shunt: does the approach matter? Heart Lung Circ 19:460-464

2. Ahmad U, Fatimi SH, Naqvi I, Atiq M, Moizuddin SS, Sheikh KB et al (2008) Modified Blalock-Taussig shunt: immediate and short-term follow-up results in neonates. Heart Lung Circ. 17:54-58

3. Odim J, Portzky M, Zurakowski D, Wernovsky G, Burke RP, Mayer JE Jr et al (1995) Sternotomy approach for the modified Blalock-Taussig shunt. Circulation. 92(9 Suppl):II256-||261

4. de Leval MR, McKay R, Jones M, Stark J, Macartney FJ (1981) Modified BlalockTaussig shunt. Use of subclavian artery orifice as flow regulator in prosthetic systemic-pulmonary artery shunts. J Thorac Cardiovasc Surg. 81:112-119

5. Alkhulaifi AM, Lacour-Gayet F, Serraf A, Belli E, Planche C (2000) Systemic pulmonary shunts in neonates: early clinical outcome and choice of surgical approach. Ann Thorac Surg. 69:1499-1504

6. Mihaljevic T, Cohn LH, Unic D, Aranki SF, Couper GS, Byrne JG (2004) One thousand minimally invasive valve operations: early and late results. Ann Surg 240:529e34

7. Grossi EA, Galloway AC, LaPietra A, Ribakove GH, Ursomanno P, Delianides J et al (2002) Minimally invasive mitral valve surgery: a 6-year experience with 714 patients. Ann Thorac Surg 74:660e4

8. Svensson LG, Atik FA, Cosgrove DM, Blackstone EH, Rajeswaran J, Krishnaswamy $G$ et al (2010) Minimally invasive versus conventional mitral valve surgery: a propensity-matched comparison. J Thorac Cardiovasc Surg 139:926e32

9. Hsiao CY, Ou-Yang CP, Huang CH (2012) Less invasive cardiac surgery via partial sternotomy. J Chin Med Assoc. 75(12):630-634

10. Dirks V, Prêtre R, Knirsch W, Valsangiacomo Buechel ER, Seifert B, Schweiger M, Hübler M, Dave H (2013) Modified Blalock Taussig shunt: a not-so-simple palliative procedure. Eur J Cardiothorac Surg. 44(6):1096-1102

11. Amato JJ, Marbey ML, Bush C, Galdieri RJ, Cotrone JV, Bushong J (1988) Systemic-pulmonary polytetrafluoroethylene shunts in palliative operations for congenital heart disease. J Thorac Cardiovasc Surg 95:62-69

12. Bonacchi M, Prifti E, Giunti G, Frati G, Sani G (2002) Does ministernotomy improve postoperative outcome in aortic valve operation? A prospective randomized study. Ann Thorac Surg 73:460-465; discussion 465- 466

13. Aris A, Cámara ML, Montiel J, Delgado L, Galán J, Litvan H (1999) Ministernotomy versus median sternotomy for aortic valve replacement: a prospective, randomized study. Ann Thorac Surg 67:1583-1587; discussion 1587-1588

14. Laussen PC, Bichell DP, McGowan FX, Zurakowski D, DeMaso DR, del Nido PJ (2000) Postoperative recovery in children after minimum versus full length sternotomy. Ann Thorac Surg 69:591-596

15. Perrotta S, Lentini S (2009) Ministernotomy approach for surgery of the aortic root and ascending aorta. Interact Cardiovasc Thorac Surg. 9(5):849-858

\section{Publisher's Note}

Springer Nature remains neutral with regard to jurisdictional claims in published maps and institutional affiliations. 